\title{
TŁUMACZENIA
}

Warszawskie Studia Pastoralne UKSW

Rok XII 2017 Nr 1(34)

KLAUS LÜDICKE*

\section{AMORIS LAETITIA - SPOJRZENIE KANONISTY ${ }^{1}$}

„Biorąc pod uwagę niezliczoną różnorodność konkretnych sytuacji (...) można zrozumieć, że nie należy oczekiwać od Synodu ani też od tej adhortacji nowych norm ogólnych typu kanonicznego, które można by stosować do wszystkich przypadków"2. Jest to jedno z nielicznych odwołań do prawa Kościoła, jakie czyni adhortacja apostolska papieża Franciszka.

Skoro zatem Amoris laetitia nie zawiera żadnych prawnych regulacji, zrozumiałe jest, że do tej pory ze strony kanonistów nie pojawiły się żadne opinie. Jednak brak wyraźnych unormowań kanonicznych nie oznacza, aby nie można było dostrzec pewnych konsekwencji, jakie ta enuncjacja pociąga za sobą dla prawa kanonicznego. Problemu nie stanowi tu nierozerwalność małżeństwa, której adhortacja nie kwestionuje ${ }^{3}$. Nasza

* Klaus Lüdicke (ur. 1943 r.) jest emerytowanym profesorem prawa kanonicznego. Od 1980 do 2008 był związany z Wydziałem Prawa Kanonicznego na Uniwersytecie w Münster. Autor m.in.: Der kirchliche Ehenichtigkeitsprozeß nach dem Codex Iuris Canonici von 1983. Normen und Kommentar [Münsterischer Kommentar zum Codex iuris canonici. Beiheft. 10], Essen 1994; „Dignitas connubii“. Die Eheprozeßordnung der katholischen Kirche. Text und Kommentar [Münsterischer Kommentar zum Codex iuris canonici, Beiheft 42], Essen 2005; Die Nichtigerklärung der Ehe - Materielles Recht, Essen 2012; Bischöfliches Offizialat Münster (Hrsg.), Geschieden? Wiederverheiratet? Mit der Kirche?, Freiburg 2012.

1 Tekst oryginału: Amoris laetitia - ein kirchenrechtlicher Blick, Münsteraner Forum für Theologie und Kirche (MFThK), www.theologie-und-kirche.de/amoris-laetitia-kirchenrechtlich.pdf (dostęp: 02.10.2016 r.).

2 Franciszek, Amoris laetitia, nr 300 [dalej skrót: AL].

3 Kwestionuje się nierozerwalność małżeństwa, jeśli przedmiotem dyskusji czyni się dopuszczalność drugiego małżeństwa. AL nie włącza jednak tego zagadnienia w swoje rozważania. 
uwaga zwraca się raczej na rozdział ósmy, co zresztą zdaje się sugerować sam papież Franciszek, wskazując, że właśnie ta część dokumentu prawdopodobnie może zyskać największe zainteresowanie (AL 7). Ów ósmy rozdział traktuje między innymi o tak zwanych „nieregularnych sytuacjach”, obejmujących: wspólnoty niemałżeńskie, typowe małżeństwa cywilne oraz ponowne małżeństwa osób rozwiedzionych.

\section{Tradycyjna argumentacja}

Przypomnijmy najpierw racje dla wykluczenia rozwiedzionych żyjących w nowych związkach. Otóż racje te znajdują swe uzasadnienie w kan. $915 \mathrm{KPK}^{4}$. Oto bowiem życie w drugim małżeństwie zostało tu jednoznacznie ${ }^{5}$ zakwalifikowane jako permanentne cudzołóstwo, a tym samym okoliczność trwania w ciężkim grzechu, zwanym też grzechem śmiertelnym i jest sytuacją, w której człowiek wskutek swej decyzji i swojego czynu „świadomie i w sposób wolny odrzuca Boga, Jego prawo, ofiarowane człowiekowi przez Boga przymierze miłości”6. Ów wyrażony w stwierdzeniu „świadomie i w sposób wolny” komponent mentalny, uzależniający kwalifikację ludzkiego postępowania od subiektywnego przekonania "grzesznika”, zepchnięty został w obowiązującej doktrynie kanonistycznej na boczny plan, skoro dla kan. 915 przyjęto sytuację grzechu obiektywnego, która wyraża się w sposobie życia osób żyjących w nowych związkach i która - jako taka - może być postrzegana (oceniona) przez osoby postronne. Toteż zdecydowana większość kanonistów opowiedziała się za wyjaśnieniem, jakie w związku z kan. 915 przedłożyła Komisja ds. Reformy Kodeksu Prawa Kanonicznego, odpowiadając na pytanie, czy kanon dotyczy także osób żyjących w nowym małżeństwie. Odpowiedź wówczas brzmiała: „Certo certius textus respicit etiam divortiatos

${ }^{4}$ Kan. 915 KPK brzmi: „Do Komunii świętej nie należy dopuszczać ekskomunikowanych lub podlegających interdyktowi, po wymierzeniu lub deklaracji kary, jak również innych osób trwających z uporem w jawnym grzechu ciężkim”.

5 Wyjątek stanowi Matthäus Kaiser, Geschieden und wieder verheiratet, Regensburg 1983.

${ }^{6}$ Jan Paweł II, Reconciliatio et poenitentia. Adhortacja apostolska (1984), nr 17.

$$
|242|
$$


et renuptiatos” - w sposób niewątpliwy tekst dotyczy także rozwiedzionych w ponownych małżeństwach ${ }^{7}$.

Różne dyscypliny teologiczne, w sposób sobie właściwy, podjęły wysiłek na rzecz dopuszczenia osób, które zawarły nowy związek, kwestionując nierozerwalność małżeństwa, szukając przy tym odpowiedniej argumentacji: biblijnej, historycznej, antropologicznej, dogmatycznej i innych ${ }^{8}$, aby ominąć kwalifikację ponownego małżeństwa uznanego za cudzołóstwo. Tematyzowanie wprost moralnoteologicznej oceny życia w drugim (kościelnie nieważnym) małżeństwie jest nieskuteczne z powodu rygorystycznego żądania zasady: omne peccatum contra Sextum mortale, jakiej domaga się Magisterium Kościoła. Na to, że w przypadku wykluczenia osób żyjących w nowym związku nie chodziło w rzeczy samej o sprzeczność między Eucharystią z jednej strony czy o małżeństwo będące obrazem urzeczywistniającym przymierze Chrystusa z Kościołem - jak to ujmuje Jan Paweł II w Familiaris consortio $\mathrm{nr} 84^{9}$ - z drugiej, lecz o zdecydowany zakaz obcowania płciowego, wskazuje już ów dokument w swej propozycji otwarcia drogi do sakramentu pokuty i Eucharystii poprzez naznaczony wstrzemięźliwością charakter takiego pożycia ${ }^{10}$.

Reasumując, oznacza to: wspólnota życia dwojga, poślubionych nieważnie z punktu widzenia Kościoła, osób, uzasadniona in foro externo, a więc w sposób zewnętrzny i pozwalający przypuszczać, że żyją w cudzołóstwie i są w związku z tym ciężkimi grzesznikami,

7 Relatio complectens synthesim animadversionum... ad novissimum Schema Codicis Iuris Canonici exhibitarum, Vatikan 1981, s. 214.

8 Por. choćby przyczynki zawarte w tomie pod red. Thomas Schneider: Geschieden - wiederverheiratet - abgewiesen?, Freiburg 1995 (QD 157).

9 Jan Paweł II, Familiaris consortio. Adhortacja apostolska (1981).

10 „Pojednanie w sakramencie pokuty, które otwiera drogę do sakramentu Eucharystii, może być przyznane jedynie tym, którzy... mają uczciwą gotowość do życia, które nie sprzeciwia się nierozerwalności małżeństwa. Oznacza to konkretnie, że... «zobowiązują się oni, aby żyć we wstrzemięźliwości, a więc powstrzymywać się od aktów, które są zastrzeżone małżonkom»" (FC 84 pod cytatem homilii papieża na zakończenie Synodu biskupów 25 października 1980). Odsyłając do GS art. 51, AL w przypisie 329 nazywa je sprzeciwami wobec żądania wstrzemięźliwego życia. 
a ponieważ nie chcą zaniechać tego związku, podlega kan. 915 i nie mogą oni zostać dopuszczeni do Eucharystii ${ }^{11}$.

\section{Perspektywy Amoris laetitia}

W przywołanym wcześniej fragmencie (nr 84) Familiaris consortio Jan Paweł II zwrócił się z wezwaniem, „aby dla miłości prawdy... dobrze rozróżniać różne sytuacje. Jest bowiem różnica, czy ktoś, mimo uczciwych starań, aby ratować wcześniejsze małżeństwo, zupełnie niesłusznie został porzucony, czy ktoś zburzył swoje ważne zawarte małżeństwo z powodu ciężkiej winy”. Dokument nie dopuszcza jednak żadnych konsekwencji w wyniku takiego rozróżnienia.

Wyraźnie nawiązując do Familiaris consortio, papież Franciszek w nr 298 swej ostatniej adhortacji podejmuje konieczność rozróżniania: należy przezwyciężać różne sytuacje życiowe (AL 298), różne formy wykluczenia (AL 299), różne kwalifikacje wykroczeń przeciw normie: „A ponieważ «różny stopień odpowiedzialności (...) nie jest równy we wszystkich przypadkach» $\left.{ }^{335}\right]$, należy uznać to rozróżnienie, że konsekwencje czy skutki normy nie koniecznie zawsze muszą być takie same.[ ${ }^{336}$ ]" (AL 300$)^{12}$. Tym samym papież podprowadza pod centralną wypowiedź, jaką znajdujemy w AL 301:

Kościół dysponuje solidną refleksją na temat uwarunkowań i okoliczności łagodzących. Dlatego nie można już powiedzieć, że wszyscy, którzy są w sytuacji tak zwanej „nieregularnej”, żyją w stanie grzechu śmiertelnego, pozbawieni łaski uświęcającej. Ograniczenia nie zależą tylko od ewentualnej nieznajomości normy. Podmiot, choć dobrze zna normę, może mieć duże trudności w zrozumieniu „Wartości zawartych w normie moralnej”[ $\left.{ }^{399}\right]$, lub może znaleźć się

\footnotetext{
11 Oczywiście, w tym ujęciu, należy im odmówić także rozgrzeszenia w sakramencie pokuty, ponieważ nie są oni gotowi do zaprzestania cudzołożnego związku.

12 Przypis 335 odwołuje się do Relatio finalis Synodu Biskupów, ale przypis 336 wyprowadza: „Nawet, gdy chodzi o dyscyplinę sakramentalną, ponieważ po rozeznaniu można uznać, że w danej sytuacji nie ma poważnej winy. Stosuje się tutaj to, co powiedziałem w innym dokumencie: por. Evangelii gaudium. Adhortacja apostolska (2013), nr 44, 47, AAS 2013, nr 105, s. 1038-1040”.
} 
w określonych warunkach, które nie pozwalają mu działać inaczej i podjąć inne decyzje bez nowej winy ${ }^{13}$.

W nawiązaniu do nr 1735 Katechizmu Kościoła Katolickiego papież Franciszek pisze o różnych czynnikach, mających wpływ na moralną odpowiedzialność człowieka:

Z tego powodu, negatywny osąd odnośnie do sytuacji obiektywnej nie oznacza orzeczenia o odpowiedzialności lub winie danej osoby $\left.{ }^{345}\right]^{14}$.

\section{A dalej papież wywodzi w AL 305:}

W związku z tym duszpasterz nie może czuć się zadowolony, stosując jedynie prawa moralne wobec osób żyjących w sytuacjach „,,nieregularnych", jakby były kamieniami, które rzuca się w życie osób. Tak jest w przypadku zamkniętych serc, które często chowają się nawet za nauczaniem Kościoła, aby „zasiąść na katedrze Mojżesza i sądzić, czasami z poczuciem wyższości i powierzchownie, trudne przypadki i zranione rodziny" $\left.{ }^{349}\right]$. Ze względu na uwarunkowania i czynniki łagodzące możliwe jest, że pośród pewnej obiektywnej sytuacji grzechu osoba, która nie jest subiektywnie winna albo nie jest w pełni winna, może żyć w łasce Bożej, może kochać, a także może wzrastać w życiu łaski i miłości, otrzymując w tym celu pomoc Kościoła $\left[{ }^{351}\right]^{15}$.

13 Obecny cudzysłów przy słowie „nieregularny” występuje w oryginale, zaś przypis 336 odwołuje się do Familiaris consortio.

14 AL 302. Fakt, że przypis 345 odwołuje się do deklaracji Papieskiej Rady ds. Interpretacji Tekstów Prawnych z 24 czerwca 2000 r., odrzucając (zauważoną przeze mnie) niestosowalność kan. 915 do osób żyjących w nowym związku, jest przykładem argumentacji zaoferowanej przez papieża Franciszka. Deklaracja mówi tylko w zdaniu pobocznym, że szafarz Komunii św. nie może ocenić subiektywnej dopuszczalności. Sentencją deklaracji, której papież nie cytuje, jest uwaga, że żyjący w „habitualnie ciężkim grzechu” są niegodni uczestniczenia w Eucharystii i dlatego muszą być jej pozbawieni. Powodem tego jest stwierdzenie, nie przystające do myślenia papieża, że: „Istotnie, przyjmowanie Ciała Chrystusa w stanie jawnej niegodności wyrządza obiektywną szkodę wspólnocie kościelnej; takie postępowanie narusza prawo Kościoła i wszystkich wiernych do życia zgodnego z wymaganiami tej wspólnoty".

15 Zacytujmy tu przypis 351: „W pewnych przypadkach mogłaby to być również pomoc sakramentów. Dlatego „kapłanom przypominam, że konfesjonał nie powinien być salą tortur, ale miłosierdziem Pana" (Adhortacja apostolska Evangelii gaudium 


\section{Podsumowanie kanoniczne}

Wystarczy, że wskażemy tylko dwa momenty. Jeśli obiektywna sytuacja „nieregularnej” sytuacji nie pozwala na osąd, czy człowiek w swym położeniu znajduje się w grzechu śmiertelnym i tym samym utracił łaskę uświęcającą, to nie sposób uznać życia w nieważnym drugim małżeństwie za „habitualnie ciężki grzech”. Skoro obiektywna sytuacja nie zezwala na sąd co do statusu grzechu osoby, szafarz Komunii św. nie jest w stanie zweryfikować supozycji kan. 915, bądź się jej podporządkować. Wszyscy wierni, także żyjący w nowych związkach, mają zatem zagwarantowane kan. 912 prawo do należnej Eucharystii.

Ale pozostaje inna kwestia (co kan. 916 KPK wyraża językiem prawniczym ${ }^{16}$ ): „Dlatego też kto spożywa chleb lub pije kielich Pański niegodnie, winny będzie Ciała i Krwi Pańskiej. Niech przeto człowiek baczy na siebie samego, spożywając ten chleb i pijąc z tego kielicha. Kto bowiem spożywa i pije nie zważając na Ciało (Pańskie), wyrok sobie spożywa i pije" (1 Kor 11,27-29). Ta odpowiedzialność ciąży na każdym, kto przystępuje do sakramentu Eucharystii i żadna instancja nie może zwolnić z tego obowiązku: „Jesteśmy powołani do kształtowania sumień, nie zaś domagania się, by je zastępować” (AL 37).

tłum. Rafał J. Kupiszewski

[24 listopada 2013 r.], 44. Zaznaczam również, że Eucharystia „nie jest nagrodą dla doskonałych, lecz szlachetnym lekarstwem i pokarmem dla słabych” (tamże, 47)". Zniesienie założenia grzechu śmiertelnego, oznaczające dostęp do spowiedzi i Eucharystii, zostaje zatem ukryte w jednym z przypisów!

16 „Kto ma świadomość grzechu ciężkiego, nie powinien bez sakramentalnej spowiedzi odprawiać Mszy św. ani przyjmować Komunii świętej, chyba że istnieje poważna racja i nie ma sposobności wyspowiadania się. W takim jednak wypadku ma pamiętać o tym, że jest obowiązany wzbudzić akt żalu doskonałego, który zawiera w sobie zamiar wyspowiadania się jak najszybciej”. 